\title{
Technology Used in Knowledge Management by Global Professional Event Services
}

\author{
Krzysztof Borodako, Cracow University of Economics, Poland \\ (iD) https://orcid.org/0000-0002-7348-8372 \\ Jadwiga Berbeka, Cracow University of Economics, Poland \\ Michał Rudnicki, Cracow University of Economics, Poland \\ iD https://orcid.org/0000-0003-3310-8117
}

\begin{abstract}
Professional service providers, due to their use of information and communication technology (ICT), could be global players. The market for congresses, conferences, trade shows, and business events attract clients and contractors from around the world. Competition between firms motivates them to apply advance technologies that enable faster and easier cooperation. The aim of this exploratory study was to identify and classify ICT used in knowledge management among professional event service providers. By applying method triangulation (interviews, meta-linguistic coding, analysis of association graphs, and netnography), the authors identified key terms related to knowledge management and technology. Firms differed by type and length of market presence. The technologies used by firms were grouped into five types. The analysis of competition in search engines confirm high scores for technology service providers (i.e., cloud data and beacon).
\end{abstract}

\section{KEYWORDS}

Business Services, Cloud Data, Co-Creation, Global Events, Information Communication Technology (ICT), Knowledge, Netnography, Visualization

\section{INTRODUCTION}

Modern technologies are the foundation for global professional business services and nowadays, they face the objective necessity of using new information and communication technologies (ICT) (Thurston \& Singh, 2010). They constitute a basic tool in knowledge transfer processes - mutual generation and accumulation of knowledge between participants on the B2B market (Nonaka \& Takeuchi, 2006). The pace of changes in technological development implicating diversity in communication technologies (Frank et al., 2019) determines the use of dynamic knowledge management processes for the successful achievement of goals by all stakeholders (Heinrichs \& Lim, 2005). Suppliers of professional event services operating in the meeting industry worldwide (ICCA, 2018b) use 
them in particular with entities involved in event planning and organization (Rogers, 2008). Proper knowledge management processes acquire particular significance here, as these service suppliers are characterized by high-intensity knowledge (Borodako, Berbeka, \& Rudnicki, 2016), especially in the field of tacit knowledge, one of the qualifying features for inclusion in knowledge-intensive business services (KIBS) (Segal-Horn, 2006; Tether, 2005). The use of various ICTs in knowledge management processes by providers of professional event services is part of the SECI model (Nonaka \& Toyama, 2007) which underlines the importance of knowledge in relationships with contractors.

The literature concerning knowledge transfer via KIBS is rich. The same can be seen in the context of ICT issues. KIBS and ICT issues taken together in the field of knowledge management are much less frequently the subject of analysis, while there is virtually no research devoted to the new category of KIBS, which are professional event services. Existing research mainly concerns the relationship between KIBS and ICT as equal partners for cooperation and diffusion of knowledge (Kamp \& Sisti, 2018; Ramadan, Dahiyat, Bontis, \& Al-dalahmeh, 2017), the impact of ICT providers (as one of the types of KIBS) on the condition of companies (Vergara \& Feldman, 2018; Kite, 2018) and/or on the whole economy (Broersma \& Van Ark, 2007), and their influence on innovation performance (Audretsch \& Belitski, 2018; Yan, Wen, \& Huesig, 2010). While these studies have uncovered mutual relations between KIBS and ICT providers as entities cooperating with each other in knowledge transfer processes, the methods and techniques of using ICT among providers of professional business services still needs to be explored. This paper bridges that gap and identifies and classifies the use of ICT in knowledge management among providers of professional business services that organize meetings worldwide. To achieve this goal, it was decided to examine what methods are used by event organization companies to absorb and transfer knowledge, how companies offering professional business services differ in their approach to knowledge and technology management, what technological solutions are used by companies organizing events and what are the dominant keywords related to event organization services in an Internet search engine. Answers to the research questions posed were based on the results of exploratory research involving 21 interviews conducted with managers or owners of well-known companies organizing international events based in Poland. Moreover, empirical research on knowledge management in the service industry is sparse (Preece 2015), so the results of this research will fill in this second gap.

This article has five sections, including this introduction. The second presents a review of the literature on the topic of knowledge in global services, the role of ICT in global services and professional event services as one type of KIBS. In the third section, the methodology used to achieve the proposed goal is described. The fourth section outlines the results of the research. Finally, the fifth section comprises a discussion, conclusions, and an examination of the limitations of the study and directions for future research.

\section{BACKGROUND}

\section{Knowledge in Global Services Resources}

Knowledge is globally perceived as a crucial resource on a micro (company) and macro (economy) scale. With respect to the former level, in light of the knowledge based-view of an organization (Spender, 1996; Nonaka \& Toyama, 2007) highlighted two dominant goals of a firm: the generation and application of knowledge (Nonaka \& Takeuchi, 2006). The competence to reach both aims is considered one of the main sources of a firm's competitive advantage (Spender, 1996; Zollo \& Winter, 2003). Achieving these aims requires dynamic knowledge management (Heinrichs \& Lim, 2005). Hoegl and Schulze (2005) offered a model based on historical perspective with three phases of company knowledge management: 1 . Capturing and locating: comprising data and information processing and information systems management. 2. Transferring and sharing: knowledge management focused on the organizational knowledge sharing process. 3. Creating and enabling: management comprising 
the sources and factors that promote knowledge creation. These days, business knowledge is created through dynamic interactions with the environment. Nonaka and Toyama's (2007) contribution to knowledge creation theory development integrates the knowledge creation process with location and enabling conditions (leadership, organizational culture, learning). The model consists of seven components: the SECI model, knowledge vision, driving objectives, $B a-$ an existential space for the SECI process, knowledge assets and the environment (Nonaka \& Toyama, 2007). The SECI (Socialization - Externalization - Combination - Internalization) model represents the process of knowledge creation through dialog between tacit and explicit knowledge. $B a$ (a Japanese expression without a proper English translation) is the shared context for knowledge creation, while knowledge assets include the inputs, outputs, and moderators of the knowledge creation process. This theory emphasizes the importance of knowledge context and promoting the right conditions within an organization.

Nonaka and Toyama's (2007) model describes the transformation of individual knowledge into group knowledge, and then the transformation of group knowledge into organizational knowledge, with possible reverse transfer from the organization to the group and individual. Furthermore, the organization may exchange knowledge with the operational environment, or knowledge ecosystem (Bratinau \& Orzea, 2010). The process of knowledge creation and dissemination is also described in Nissen's model (2006) and is called flow. A succession of other models has been developed, such as Boisot's model (1999), EO-SECI model (Martin de Castro, Saez, \& Lopez, 2008), which can be called knowledge dynamics models. They try to explain organizational knowledge creation from a larger perspective of both tacit and explicit knowledge. Such a process of creation and dissemination, strongly supported by ICT as a moderating factor, with respect to the models mentioned above can be observed in business service companies.

Empirical research on knowledge management in the service industry is sparse (Preece, 2015), which motivated the authors in carrying out this research. Moreover, business services are activities that require advanced technology and a relatively highly skilled workforce to fully benefit from technological innovations (Gayá, 2018). That is why all aspects - knowledge and technology, and the spillover effect - are taken into consideration.

\section{Information and Communication Technology in Global Services}

In this section, the authors outline the information and communication technologies used and researched in the business service sector with a special focus on international players. This study was based on the definition of technology used by Bouwman et al. (2005) as a tool to organize things in a different manner, coordinate processes and perform tasks more easily and efficiently. It should be stressed that technology does not only refer to physical devices such as mobile phones or computers (Martinez, Vazquez, Estrada, Santillan, \& Zavala, 2017), but also to a system that provides mechanisms facilitating the transmission, processing and storage of information within an organization.

Professional service providers are under pressure from global competitors who combine technology, innovative business models and global networks on the international market (Thurston \& Singh, 2010). The key aspects of professional service delivery and a firm's competitiveness on the global market involve new technologies including information processing (Lovelock, 1995). At the same time, services based on technological solutions contribute to new applications of other ICT in business. Frank, Dalenogare and Ayala (2019) proposed a division between front-end and base technologies, where base technologies refer more specifically to business services. They suggested that this group of technologies includes the Internet of Things, cloud services, big data and analytics. The next paragraphs feature a brief discussion concerning selected technologies that can be classified as base technologies such as mobile tech, cloud services and visualization.

Within more widely understood services and technologies related to ICT, the most common might be mobile technologies. Wang et al. (2019) stated that in addition to traditional mobile services like voice and text messaging, recent mobile services offer a broad spectrum of applications and 
value-added services. Many of them support faster and easier communication with clients, peers and business partners. User satisfaction with mobile services is strongly correlated with the quality of communication delivered by these services (Gerpott, Rams, \& Schindler, 2001).

In the current business environment, cloud services for the $\mathrm{B} 2 \mathrm{~B}$ market are gaining popularity. Cloud service models can be offered in various formats such as Infrastructure as a Service (IaaS), Platform as a Service (PaaS), Software as a Service (SaaS) and X as a Service (XaaS) (Armbrust et al., 2010). Xaas is mostly dedicated to clients on the B2C market like games or music (e.g. Spotify or Tidal). In the present study, the authors researched all B2B cloud service formats where products or services are offered directly to another business - in this case to event business service providers or their clients.

One of the global technology solutions used by professional service providers is visualization. The intangibility of event services makes it difficult for partners to fully understand the advantages and uniqueness of the proposed event concept during the pre-purchase stage as well as the realization stage. Legg and Baker (1987) pointed out this problem in the service sector in both phases - pre-purchase and also post-purchase. For international business events, international trade fairs or international congresses, the event owner may only visit the destination (site) a few times before the event and usually manages the whole process from another country or continent (Borodako et al., 2015). In this case, perfect communication and visualization can improve the process of event co-creation. Visualization services are offered on the technological market by traditional databases and analytic services and software companies (Urbinati, Bogers, Chiesa, \& Frattini, 2019). But visualization is also a key element for architecture and design service providers who can offer professional exterior architecture visualizations, photorealistic interior visualizations and virtual walks (Lowe \& Ploetzner, 2017). All these services are based on advanced knowledge and are competitive on an international level. There are three value categories in visualization services, namely product-based, service-based and relationship-based (Ulaga \& Eggert, 2006), but the last category is commonly recognized as very difficult to create (Mathieu, 2001). As presented in this section, technologies are a fundamental element of professional service delivery but their incorporation in the international events industry is still poorly understood.

\section{Global Professional Event Services as Knowledge-Intensive Business Services}

Professional event organization providers have at their disposal conceptual, organizational and often executive facilities for the organization of all kinds of events, e.g. conventions, conferences, workshops, seminars, congresses, fairs, expositions, exhibitions, and all other types of business meetings (Crouch \& Ritchie, 1998; Davidson \& Cope, 2003; Dotson, 1995; Rogers, 2008; UNWTO, 2006). These include mainly three groups of entities: event agencies, incentive/tour operators and Professional Congress Organizers (PCO) and Destination Management Companies (DMC) (Borodako et al., 2015). Reports prepared annually by leading associations such as the International Congress and Convention Association (ICCA), Union of International Associations (UIA) and Global Association of the Exhibition Industry show the clear dynamic growth (the number of international association meetings doubled every 10 years - ICCA, 2018c) and global meaning of this market. The meeting industry is one of the fastest growing segments in tourism (Martín, Román, \& Gonzaga, 2017) and has both direct and indirect impact on the local (Borodako et al., 2019; Grado, Strauss, \& Lord, 1998) and global economy (ICCA, 2018c). Although global data is difficult to assess, numerous examples of meetings industry impact on the economies of individual countries can be found (Mair, 2015). In the US alone, which occupies a leading position, the last report illustrates that the meeting and event industry continues to grow across all segments, contributing hundreds of billions of dollars in revenue to the US economy and providing 5.9 million jobs (ICCA, 2018b).

Besides economic benefits, the meeting industry delivers opportunities for knowledge sharing and networking not only for meeting participants (Rogers, 2008; Whitfield, Dioko, Webber, \& Zhang, 2014) but primarily for professional event services organizers and other entities involved in their organization, 
making it an important driver for intellectual development and regional, national and global cooperation (Borodako et al., 2015; Leszczynski, Zmyślony, \& Zieliński, 2014). An event organization service is a cycle of activities, including design, planning, organization, production and evaluation connected with events that realize business objectives with respect to the external and internal environment: clients, decision-makers, partners, opinion-making groups and employees. That is why people are a key element of production; human capital/social capital and technological know-how are major input factors (Janakiraman, 2012; Jansen, Curşeu, Vermeulen, Geurts, \& Gibcus, 2011). Their knowledge and participation in various activities is their main contribution and that is why professional event services are treated as knowledge-intensive business services (KIBS) (Borodako et al., 2016). As Amara and others have noted, the core competence of KIBS resides in their capability to combine, in a unique body of knowledge, codified scientific and technical knowledge with tacit knowledge based on extensive experience to address specific customer problems (Amara, D'Este, Landry, \& Doloreux, 2016). Event services, much like other KIBS, are characterized by a high degree of tacit knowledge (Hu, Chang, Lin, \& Chien, 2006; Segal-Horn, 2006; Tether, 2005; Windrum \& Tomlinson, 1999). They support and create innovation and "customization", in other words unique solutions linked to tacit knowledge that demonstrate a high degree of interaction between service suppliers and clients, much like other KIBS (Camacho \& Rodriguez, 2005; Muller \& Doloreux, 2009).

In the knowledge management process, professional event services create new knowledge, which in turn increases the likelihood of innovation (Amara, Landry, \& Doloreux, 2009; Landry, Amara, Lamari, \& Ouimet, 2007). Thanks to the use of advanced technologies and ICT, they create new opportunities for experimenting and solving problems of contractors that would otherwise be impossible (Madsen \& Desai, 2010; Magazzini, Pammolli, \& Riccaboni, 2012). Numerous examples of the impact of technology on knowledge management processes in KIBS can be found in the literature, e.g. research conducted by Torre and Rallet (2005) or Amara et al., (2016). Pina and Tether (2016) found that recent investments in information technologies were associated with product/service innovation among KIBS within all three knowledge bases - synthetic, analytical and symbolic knowledge (SAS model). This indicates that IT investments are particularly important for innovation among KIBS.

\section{RESEARCH METHODOLOGY}

\section{Research Process}

Triangulation of methods was used to acquire and analyze data. In the first stage, direct individual interviews were conducted (semi-structured interviews based on face-to-face and direct communication) with representatives of companies. Then these results were supplemented based on an assessment of the most frequently searched keywords related to business services associated with events. It should be emphasized that exploratory research based on interviews is relatively rarely used in research in the service industry (Lee \& Han, 2017; Lupo \& Delbari, 2018; Wollersheim, Pfaff, \& Krcmar, 2014). This method, on the other hand, is an appropriate instrument for collecting information on expert knowledge accumulated throughout many years of professional experience (Creswell, 2003; Morse $\&$ Field, 1995). Interviews with experts allowed the authors to collect and systematize information without having to formulate hypotheses. Exploratory interviews are considered a suitable method for collecting information leading to the discovery of new research areas and development of new research theories and concepts (Brinberg \& McGrath, 1985; Creswell, 2003; Hübner, Holzapfel, \& Kuhn, 2015).

\section{Research Scope}

The aim of this exploratory research is to identify and classify the use of information and communication technologies in knowledge management in KIBS organizing international events. This 
study focuses on issues that need to be recognized from a theoretical and practical (operational) point of view. Previous research in the area of services was not dedicated to business services regarding the organization of events in the field of technologies used in knowledge management. The objectives of this exploratory study can be summarized with four research questions:

Research Question One: What methods are used by companies that organize professionally events for absorption and knowledge transfer?

Research Question Two: How do the features of companies offering professional business services differentiate their approach to knowledge and technology management?

Research Question Three: What technological solutions are used by companies that organize events?

Research Question Four: What are the dominant keywords related to event organization services in an Internet search engine?

\section{Methods}

Given the highly specialized yet poorly researched nature of the KIBS industry, the following methods were used for data collection and analysis:

1. 21 interviews were conducted with managers or owners of well-known companies organizing international events (event agencies, incentive/tour operators and PCO/DMCs) based in Poland. Interviews were analyzed using two methods:

a. Meta-Linguistic Coding: In this method the relevant criteria (job position, gender, etc.) or categories (company type, company location, etc.) which do not have to occur in the text are assigned to the text by researchers. These codes capture meaning in the data. They also serve as handles for specific occurrences in the data that cannot be found by simple text-based search techniques. Codes are used as classification devices at different levels of abstraction in order to create sets of related information units for the purpose of comparison. Their purpose is to classify an often large number of textual or other data units (Friese, 2018). In addition, all text units are categorized based on additional criteria with the aim of gathering both information on the object of analysis (e.g. company name, industry, size, etc.) and information necessary to pursue a theory-driven analysis based on the relevant research question (Hielscher \& Will, 2014). Meta-linguistic coding of all text units permits a direct analysis of the frequencies for all pairs of criteria or for any combinations of criteria, either in absolute values or by percent (Zelger, 2004);

b. Analysis of Association Graphs (Networks of Codes): This method allows us to reconstruct the meaning of a term in the context of a collected verbal database. It uses concepts as descriptions which are very often connected with the keyword in a verbal database. Association graphs are linguistic nets that represent the connections and associations between specifically coded keywords in various meaningful text units. Linguistic nets serve as orientation in a landscape of diverse opinions, perspectives and world views (Hielscher \& Will, 2014; Zelger, 2008);

2. Netnography: Whose name suggests its meaning, is a combination of words: Internet and ethnography. The main aim of this method is analysis of online communities (Kozinets, 2010), but it is also used in marketing research related to consumer behavior, needs and trends (Belk, 2017). The standard procedure for this method is based on data available directly from computermediated communications of online community members. In this study, a modified version of the method was applied, adjusting it to research on the B2B market where relationships differ from those of final consumers. Data from online tools were used by companies in their Internet marketing activities, mainly Google Adwords and KeyWords Finder (KWFinder). SEO analysis was used twice. In the first stage, the use of these tools enabled the authors to identify the key 
(most popular) terms related to the global meeting organization industry. In the second stage, the key words listed in the analysis of interviews were analyzed.

\section{RESULTS}

\section{Knowledge and Technology Management in Event Professional Services \\ Knowledge Management and Information and Communication Technology in a Diversified Environment (Interviewees) and Company Profiles}

With respect to knowledge management, it has been found that knowledge acquisition occupies a central role. This indicates the industry's recognition of the need to acquire knowledge as a priority and make this the focus at both a strategic and operational level. At the same time, mentioning meetings by interviewees in this respect indicates that they are perceived as a source of tacit knowledge, through cooperation with business partners and clients and the opportunity to observe the activity of competitors. Industry representatives also emphasized the importance of obtaining results from outsourced research and the internal exchange of information within the company. As far as technology is concerned, these results indicate that it should ensure more rapid communication in event services companies and its use enables the automation of service provision processes, visualization during meetings and data storage in the cloud, which increases access to data and the security of their storage.

Analysis using Meta-Linguistic Coding methods was also used to examine the influence of certain company characteristics on their approach to the issues of knowledge and technology (Table 1). As for the diverse opinions resulting from the interlocutor's position, respondents who were employees attached greater weight to gaining knowledge and stressed the importance of meetings in this regard. Owners, however, emphasized the internal exchange of information within the company with a wider perspective based on knowledge management and concentrated on maximum use of resources. With respect to technology, it should be pointed out that owners focused more on this aspect than employees. This was manifested in owner consideration of automation, faster communication and resource accumulation in the cloud thanks to technology.

There was also a difference in the role attributed to the aspects of knowledge and technology depending on the type of company. PCO/DMC companies paid more attention than the other categories (i.e. incentive/tour operators and event companies) to acquiring knowledge, while valuing meetings less as a source of knowledge. They also placed less emphasis than other companies on the internal acquisition of information within the company. Smaller differences were noted with respect to the approach to technology; it can be concluded that this is a universal aspect that is less dependent on the type of activity. Event companies were more focused on visualizations in terms of technology, which is understandable given the profile of their services. DMC/PCO companies more rarely referred to automation processes compared to the other two types.

Analysis of the approach to knowledge and technology according to the period of operation on the market reveals a certain dissimilarity between companies with the longest market presence (more than 30 years). Such companies show greater appreciation for the value of meetings as an important source of knowledge than younger companies, but clearly assign a lesser role to acquisition of knowledge. It might be concluded that this attitude results from their market experience. However, it should also be recognized that the companies with the longest market presence attach greater significance to commissioning research to acquire knowledge than other companies. The authors interpret this as professionalization of knowledge acquisition accompanied by trust in tacit knowledge based on the experience of their employees. These results reveal how acquiring knowledge takes on meaning as a company's market presence grows, a trend that only disappears among the most experienced companies mentioned above. It was also observed that internal information exchange is most valued by young companies with a market presence of less than 10 years. Differences are also evident with respect to the approach to technology. As a company's market presence increases over time, so does 
Table 1. Characteristics of codes mentioned by interviews according to their features (based on the Meta-Linguistic Coding method)

\begin{tabular}{|c|c|c|c|c|c|c|c|c|c|}
\hline \multirow{2}{*}{$\begin{array}{c}\text { Feature of Interviewees/Firms } \\
\text { Codes }\end{array}$} & \multicolumn{2}{|c|}{ Status } & \multicolumn{3}{|c|}{ Type of Company } & \multicolumn{4}{|c|}{ Firm's Operating Time } \\
\hline & Worker & Owner & $\begin{array}{c}\text { Event } \\
\text { Agency }\end{array}$ & $\begin{array}{l}\text { Incentive } \\
\text { /Tour } \\
\text { Operator }\end{array}$ & PCO/DMC & $\begin{array}{c}\text { up to } \\
10 y\end{array}$ & $\begin{array}{l}11- \\
20 y\end{array}$ & $\begin{array}{l}21- \\
30 y\end{array}$ & $\begin{array}{c}\text { over } \\
30 y\end{array}$ \\
\hline Acquisition & $13 \%$ & $11 \%$ & $9 \%$ & $13 \%$ & $13 \%$ & $10 \%$ & $13 \%$ & $13 \%$ & $5 \%$ \\
\hline Meetings & $13 \%$ & $9 \%$ & $11 \%$ & $12 \%$ & $9 \%$ & $12 \%$ & $8 \%$ & $10 \%$ & $24 \%$ \\
\hline Internal information exchange & $7 \%$ & $8 \%$ & $9 \%$ & $8 \%$ & $6 \%$ & $11 \%$ & $4 \%$ & $8 \%$ & $7 \%$ \\
\hline Ordering & $1 \%$ & $1 \%$ & $2 \%$ & $1 \%$ & $0 \%$ & $1 \%$ & $0 \%$ & $1 \%$ & $5 \%$ \\
\hline Benchmarking & $8 \%$ & $6 \%$ & $8 \%$ & $3 \%$ & $9 \%$ & $5 \%$ & $10 \%$ & $8 \%$ & $0 \%$ \\
\hline Interdisciplinarity & $4 \%$ & $4 \%$ & $5 \%$ & $6 \%$ & $2 \%$ & $7 \%$ & $3 \%$ & $4 \%$ & $0 \%$ \\
\hline Evaluation by client & $6 \%$ & $5 \%$ & $5 \%$ & $6 \%$ & $6 \%$ & $7 \%$ & $5 \%$ & $5 \%$ & $5 \%$ \\
\hline Teamwork & $13 \%$ & $10 \%$ & $8 \%$ & $15 \%$ & $12 \%$ & $11 \%$ & $10 \%$ & $14 \%$ & $10 \%$ \\
\hline Co-creation & $7 \%$ & $7 \%$ & $8 \%$ & $6 \%$ & $7 \%$ & $11 \%$ & $6 \%$ & $6 \%$ & $2 \%$ \\
\hline Automation & $6 \%$ & $9 \%$ & $8 \%$ & $8 \%$ & $6 \%$ & $7 \%$ & $8 \%$ & $8 \%$ & $5 \%$ \\
\hline Beacon & $0 \%$ & $1 \%$ & $1 \%$ & $1 \%$ & $0 \%$ & $1 \%$ & $1 \%$ & $1 \%$ & $0 \%$ \\
\hline Faster communication & $8 \%$ & $12 \%$ & $10 \%$ & $10 \%$ & $10 \%$ & $7 \%$ & $13 \%$ & $10 \%$ & $15 \%$ \\
\hline Technology examples & $10 \%$ & $11 \%$ & $9 \%$ & $9 \%$ & $13 \%$ & $6 \%$ & $15 \%$ & $10 \%$ & $15 \%$ \\
\hline Visualization & $2 \%$ & $3 \%$ & $5 \%$ & $1 \%$ & $2 \%$ & $3 \%$ & $2 \%$ & $2 \%$ & $7 \%$ \\
\hline Cloudata & $1 \%$ & $3 \%$ & $2 \%$ & $1 \%$ & $4 \%$ & $3 \%$ & $3 \%$ & $2 \%$ & $0 \%$ \\
\hline Total & $100 \%$ & $100 \%$ & $100 \%$ & $100 \%$ & $100 \%$ & $100 \%$ & $100 \%$ & $100 \%$ & $100 \%$ \\
\hline
\end{tabular}

Source: Own elaboration

the significance of rapid communication and specific technological solutions. At the same time, however, the companies with the longest market presence show less appreciation for cloud resources and automation in service provision than younger companies.

\section{Associations Between Key Communication Technology Attributes in Knowledge Management}

The second area of analysis of the data obtained during the interviews were links between the key words (codes) regarding knowledge and technology used by entrepreneurs from companies organizing international events (and thus cooperating with entities on the global market). Two analyses were conducted: in the first, the codes were limited to the four most numerous associations between the words, while in the second analysis, these associations were extended to all codes falling within the group of knowledge and technology.

Analysis of associated graphs based on limited key words (Figure 1) allowed the authors to make two important observations. First of all, most associations in respondent opinions were within a given area (knowledge or technology), i.e. "automation of customer service", "sample technical solutions" and "faster communication with clients and associates," appeared in statements strongly related to each other in technology. A similar phenomenon occurred in the case of knowledge, where the number of associations was greatest between "acquiring knowledge", "exchange of knowledge within the company" and "meetings."

A detailed analysis of interview content facilitated an attempt to classify sample technological solutions related to available services or strictly technology. The examples provided by respondents could be divided into five groups according to their functions with respect to event organization: 
- Technologies related directly to event organization, including holograms, virtual reality (VR), 3D mapping, 3D display technologies and $360^{\circ}$ panoramic screens.

- Technologies as services (applications) that ensure better communication before and during the event - social media, teamwork communication applications (such as Slack), group travel planning solutions (such as Planify), cloud disks (such as GoogleDrive, Dropbox), communication applications (such as WhatsApp or Skype) or LiveVoting.

- Communication technologies between devices during events (e.g. a simplified Internet of Things - IoT model) such as NFC Technology, WiFi, QR Code Scanners, Beacons.

- Corporate technologies used as part of the event company's internal operations - not directly related to the client, but indirectly positively influencing the event organization process -Customer Relationship Management and Content Management systems.

- Hardware technologies understood as additional modern devices used during events such as drones or robots.

Secondly, it was observed that companies operating on the basis of their specialized knowledge, generating benefits for international clients, aim to automate many service processes. These companies use specific technologies (examples of technological solutions such as beacons, cloudata, etc.) ensure faster communication with the client and other team members. In the case of event industry firms, the schedule of the project is largely determined by the event's date and the implementation of individual tasks must be matched to the schedule of other tasks. For this reason, the application of various technologies identified in the study to ensure faster communication, process automation, as well as visualization of selected effects of services provided. At the same time, the interviewed companies forced to acquire knowledge increased their competitiveness, not to mention knowledge transfer within their own organization. This is particularly important in this industry, because the process approach can be standardized within the organization, while the individual requirements and conditions for the organization of each event require a continuous and systematic exchange of knowledge between the employees of the organization. The preferred forms of acquiring knowledge both from outside the organization (externally) as well as among company employees at various levels of management takes place through meetings, i.e. oral transmission (creating information records in the form of shared documents, updated databases or e-mail correspondence).

In an analysis of the expanded list of codes associated with knowledge management and, in this context, applied technologies, researchers observed many details concerning these aspects. Knowledge management is based on a wide diversity of sources - respondents indicated client feedback (evaluation by client) and co-creation of a service with the client (co-creation), emphasized the interdisciplinarity of activity (interdisciplinarity), as well as the cyclical aspect (periodicity) of knowledge exchange. This is dictated by regular knowledge exchange between team members (consisting of co-workers and client's employees) in the form of meetings as well as individual conversations (F2F meetings). It is important to emphasize the importance of teamwork (teamwork) and the methods of creating innovative services through brainstorming and workshops. Respondents also pointed to the use of the "cloud" (cloudata) in teamwork and brainstorming; however, visualization was associated in the responses with faster communication, project evaluation (ideas) by the client and co-creation with the client of an international event (co-creation).

\section{Global Event Professional Services in SEO}

In the first stage of SEO analysis, Google AdWords was used to identify key words related to specific event services, i.e. fair \& congress, incentive travel, catering and AVL (Table 2). Words selected in this way were analyzed further using KWFinder.

By far the largest average monthly number of searches (more than 90,000) was for the word AVL. This proves the importance of subcontractors with specialist knowledge of audio and video installations as well as appropriate lighting in event organization. Significantly smaller results (about 


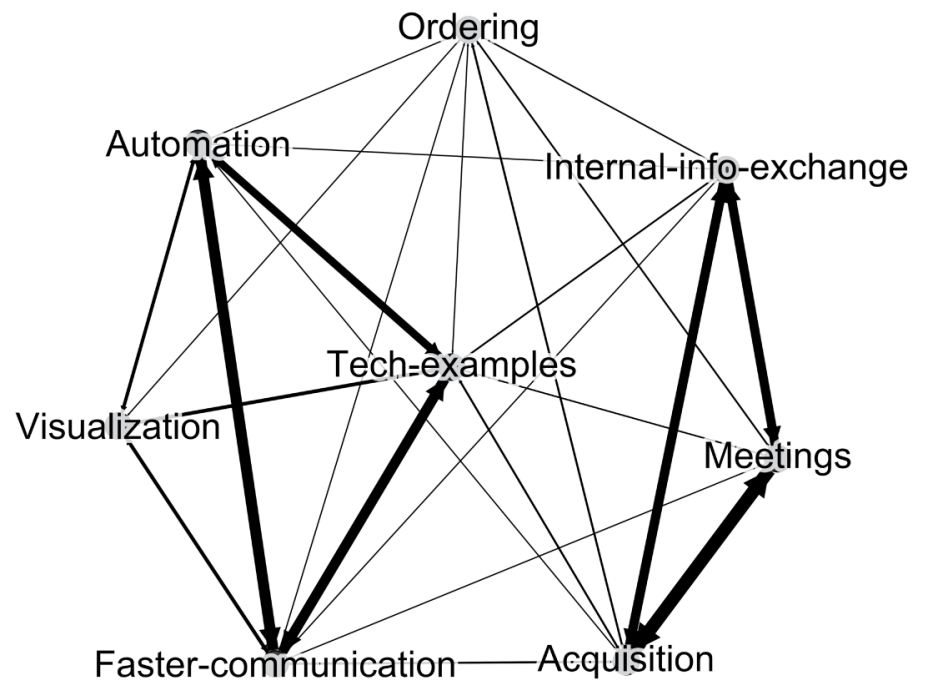

Source: Authors' own calculations

Figure 2. Association graph for knowledge and technology management by KIBS (all identified codes)

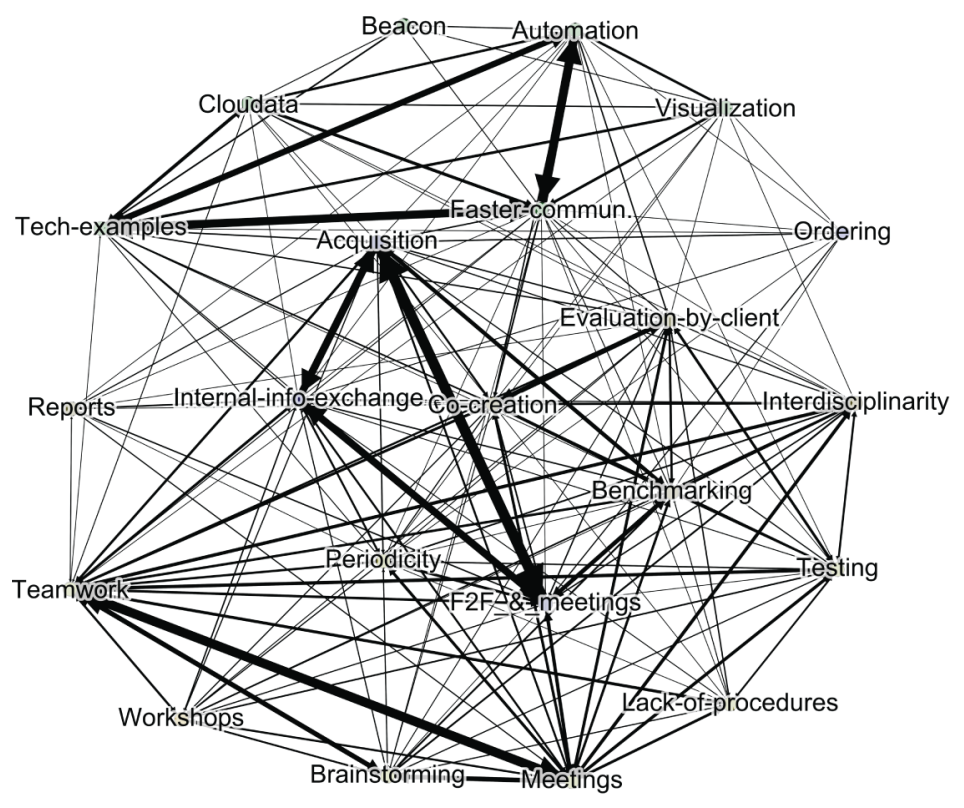

Source: Authors' own calculations

25,000 requests), although still high in comparison to other words, were categories related to catering. Gastronomic service is an inseparable element of every meeting, hence these results are not surprising.

One important element of the analysis is a measure used in online marketing (in search engine optimization) called "keyword SEO difficulty" - KD), which represents the level of competition among 
Table 2. SEO analysis for codes identified during the research process (interviews and netnography)

\begin{tabular}{|c|c|c|c|}
\hline Category & $\begin{array}{l}\text { Google AdWords (the } \\
\text { best } 3 \text { words related to the } \\
\text { main category) }\end{array}$ & $\begin{array}{l}\text { Average monthly search } \\
\text { volume in the last } 12 \\
\text { months in KWFinder }\end{array}$ & $\begin{array}{c}\text { KD (Keyword SEO } \\
\text { difficulty*) in KWFinder }\end{array}$ \\
\hline \multirow[t]{3}{*}{ fair \& congress services } & trade show booth & 4,350 & 43 \\
\hline & trade fairs & 17,768 & 58 \\
\hline & trade show & 6,622 & 58 \\
\hline \multirow[t]{3}{*}{ incentive travel } & incentive travel & 2,400 & 44 \\
\hline & incentive tour & 715 & 47 \\
\hline & incentive plan & 1,045 & 45 \\
\hline \multirow[t]{3}{*}{ catering } & box lunch & 2,6757 & 42 \\
\hline & catering services & 2,2148 & 37 \\
\hline & catering companies & 6,600 & 46 \\
\hline \multirow{3}{*}{$\begin{array}{l}\text { AVL services } \\
\text { (Audio-Video-Lightning) }\end{array}$} & AVL & 90,500 & 51 \\
\hline & AVL sound & 590 & 33 \\
\hline & AVL solutions & 170 & 20 \\
\hline \multirow{15}{*}{$\begin{array}{l}\text { Codes } \\
\text { (resulting from interviews) }\end{array}$} & Acquisition & 1,950 & 32 \\
\hline & Meetings & 4,9333 & 45 \\
\hline & $\begin{array}{l}\text { Internal information } \\
\text { exchange }\end{array}$ & 1,600 & 35 \\
\hline & Ordering & 24,6273 & 25 \\
\hline & Benchmarking & 201,940 & 46 \\
\hline & Interdisciplinarity & 3,600 & 28 \\
\hline & Evaluation by client & 1,065 & 31 \\
\hline & Teamwork & 247,090 & 48 \\
\hline & Co-creation & 18,100 & 22 \\
\hline & Automation & 164,354 & 44 \\
\hline & Beacon & 245,939 & 47 \\
\hline & Faster communication & 550,470 & 40 \\
\hline & Technology examples & 6,627 & 20 \\
\hline & Visualization & 33,188 & 36 \\
\hline & Cloud & 817,236 & 67 \\
\hline
\end{tabular}

* Based on SEO stats for pages on the first Google SERP (Min = 0; Max $=100)$.

Source: Own elaboration

keywords used to position company webpages. The higher this indicator, the greater the competition in a given area, which compels further action to ensure the website's online visibility (positioning).

It is noted that these AVL services are also one of the highest KD values. Despite the popularity of this type of online service, the competition between companies operating on this market is high. It is worth emphasizing that the vast majority of key words related to the professional event services industry are characterized by high competition ( 9 out of 12 key words with a result KD $>40$ ). On one hand, this demonstrates the necessity of ICT and its potential in B2B relationships on the global 
market for professional meeting services. At the same time, these results confirm the significance of knowledge and its flow (using other ICTs than the website of a given service provider) between individual entities in the industry, e.g. verbally transferred tacit knowledge.

The analysis also included key words related to knowledge management and, in this context, the technologies used by KIBS (identified during interviews). Very high scores were reported for words indicating processes involving managing and transferring knowledge in the company (e.g. ordering, benchmarking, teamwork - over 200,000 views) and, at the same time, for those related to ICT (cloud, faster communication, beacon, automation). These results confirm the importance of technology in knowledge management processes in global markets, which also include professional event organization services.

\section{DISCUSSION}

The research results confirm the principles indicated in knowledge dynamic models (Nissen, 2013; Nonaka \& Toyama, 2007). In the process of internal and external knowledge transfer, the components of the SECI model are visible. A very important element of both the formation (socialization process) and absorption of knowledge is dialog. Events are a space within which dialog takes place, or in other words $B a$, referring to the model developed by Nonaka and Toyama (2007). The sphere of preparing and implementing events can be called a knowledge ecosystem for the event industry. The importance of technology should be underlined as it always moderates the knowledge transfer and absorption process and represents the basis for flow, in connection with Nissen's model (2006).

The role of technology in knowledge management processes in providing professional services has been addressed by other researchers (Belal, Norani, Kosaka, Hasan, \& Nordin, 2018). They indicate that $B a$ may be created by an Internet platform (PKT-DMT Facebook community), where knowledge gathering and sharing takes place. As an example, they point to the Malaysian logistics company PKT Logistics Group Sdn Bhd (Belal et al., 2018).

In the literature concerning global services there are results - findings from Australian residential aged care organizations (Preece, 2015) - that investigate the influence of organizational characteristics on knowledge absorption and management. They reveal that the size of the organization and length of market presence did not impact absorptive capacity, their capabilities or effective knowledge management. Different approaches to technology and knowledge among more established firms and types of service providers revealed in the course of this research may be unique to event KIBS firms. Organizational and employee experience, or tacit knowledge, seems to be a crucial resource for them.

Competition on the global professional service market is very strong, which is stressed by Flynn and Kowalkiewicz (2016). They highlighted the possible strategies of incumbent professional services firms in reference to the potential entrance onto the market by Newcomers. The authors' findings concerning the event services market reveals that event organizers that compete on the global market must offer services of the highest technological level, both because of the technical advancement of their competitors as well as ordering entities (for example IT firms and other global institutions) and their expectations with respect to technology. One way of becoming technologically advanced and up to date is to integrate different types of technologies. Some of them, called disruptive innovation technologies, can be provided by Newcomers, which supports the results of Flynn and Kowalkiewicz (2016). These services usually have a supplementary character.

A similar division of services into basic and supplementary was mentioned in the work of Lovelock (1995). This is supported by the authors' findings that some services can be treated as basic and some as supplementary on the event organization market. Moreover, the research revealed a division of employees into backstage and onstage personnel (referring to Lovelock terminology). The onstage team co-creates client experiences and values. The basic value is created with the support of classical technology solutions - CRM, CMS, e-mails, social media - and additional value 
is obtained due to co-creation and supplementary services, usually based on technology (like aerial photography, cloud data).

The issue of technologies in the Industry 4.0 revolution was analyzed by Frank et al. (2019a). They distinguished between front-end technologies, systematically adopted, and base technologies, which support all dimensions of other technologies in the industry sector. These base technologies according to Frank et al., (2019b) consist of so-called new ICT, including the Internet of Things (IoT), cloud services, big data and analytics. In this research, the technologies used in the global event service industry were divided into 5 groups and the findings prove that these new ICT are present in 3 of 5 groups, so they are also significant. A special focus in professional event services can be put on cloud data services and specific IoT. Analogically to the findings of other researchers, cloud services enable on-demand network access to a shared pool of computing resources (Mell \& Grance, 2009). Moreover, it can be stressed that the authors' results highlight that visualizations can be treated as analytics of event performance and participant behavior.

\section{CONCLUSION AND MANAGERIAL IMPLICATIONS}

Analysis of the interviews and netnographic results provide conclusive answers to the authors' research questions.

As far as methods are concerned, professional event organizers acquire knowledge thanks to feedback from fellow producers, clients and participants in the process of creating events. Knowledge transfer typically involves copying new solutions created by partners and/or competitors as benchmarks and idea exchange (externally and internally). Professional organizers also acquire explicit knowledge through external research (i.e. from external companies)

The traits identified within the companies included in this research, type and duration of market presence, determined their approach to acquiring and transferring knowledge, as well as the selection of technological solutions to be used. Length of market presence plays a significant role in a company's approach to knowledge absorption and dissemination. In other words, the event organizer's life cycle influences the process of knowledge management.

The abundance of technologies mentioned by event organizers underlines their crucial role in the meeting industry. With respect to knowledge management, cloud data was identified as a very important platform for knowledge dissemination. Netnographic research indicated that AVL is currently the most interesting technology on the internet, so event organizers should ensure the high quality of this service to create a competitive advantage. The overall conclusion of the research is that knowledge, in particular tacit knowledge (i. Nonaka, 1994), is the most crucial asset for professional event organizers.

The findings show the rapid technological adaptation of the global event industry to technologically advanced fields of the economy, where entities are often the principal. They also reveal the intense competition that exists on the meetings industry market, which forces the industry to implement new technologies quickly and underlines the importance and use of these technologies in the business services industry related to international events.

Professional event services, as a specific type of KIBS, are characterized by distinctive knowledge management focused on absorption and dissemination processes.

Knowledge (tacit) absorption occurs as a direct flow (F2F) and takes place during meetings and in the process of event preparation. The authors results confirm that the SECI model (Nonaka \& Toyama, 2007) as well as dynamic management models (Nissen, 2006; Martin de Castro et al., 2008) can be used to describe the event organization market.

These findings demonstrate that modern technologies are a key moderator of the SECI model, the basis of knowledge flow, $\mathrm{Ba}$ space support or even assuming these functions. Events are the knowledge ecosystem for the meetings industry (Bratinau \& Orzea, 2010). The role of technologies is crucial for professional event organizers in knowledge dissemination (communication devices, cloud data, 
automation) and the process can be referred to using the model of knowledge flow (Nissen, 2006). The results deepen Lovelock's research on supporting complementary services through technologies such as cloud files and drones in the event organization industry. Knowledge management by event organizers also presents some features from the agile management model (Goodpasture, 2015).

Based on the findings, some managerial implications for events service providers can be formulated. Knowledge management has to be dynamic; the use of ICT is a crucial moderator of knowledge creation, transfer and absorption. Employee experience creates tacit knowledge resources, but this is not enough and must be supplemented by the ability to use new ICT. Additionally, event service providers should communicate more effectively with team members about the benefits and possibilities offered by automation and cloud data solution usage in achieving faster internal and external communication. These issues should be emphasized to a larger extent among employees by their managers to increase their positive experiences in this area and facilitate the introduction of these technologies into new event projects.

\section{LIMITATIONS AND FUTURE RESEARCH DIRECTIONS}

This research has several limitations which can point toward areas of future study. First and foremost, the interview results were exploratory in character and the sample consisted of three sub-branches (professional congress organizers, incentive travel organizations and business event agencies). There were some differences that could potentially be studied in-depth separately. Each of these sub-branches has its own characteristics and is specialized in certain technologies and service delivery processes. The research sample and exploratory study approach did not allow the authors to generalize the results to all professional event services worldwide, but many characteristics seem to be an international standard or trend in this industry. The research could have focused on manager satisfaction with particular types of technology (like mobile, cloudata, CRM, visualization, etc.), a task which could be undertaken by researchers in the future.

The second limitation of this study is that it was conducted in only one, relatively homogenous market in a Central European country, where professional event services are still undergoing intensive development. Conducted in the US or West European markets, this exploratory study could deliver new insights into the topic in the future. Future research could also examine the relationship between client (event owner) satisfaction and the level of technological engagement in the pre-event and event phase of organization. The authors are aware that this study delivered interesting results, however its replication in different contexts and cultures could provide further validation of the current findings.

\section{ACKNOWLEDGMENT}

Project financed from National Science Center (Poland) grant no. 2016/23/B/HS4/03011. 


\section{REFERENCES}

Amara, N., D'Este, P., Landry, R., \& Doloreux, D. (2016). Impacts of obstacles on innovation patterns in KIBS firms. Journal of Business Research, 69(10), 4065-4073. doi:10.1016/j.jbusres.2016.03.045

Amara, N., Landry, R., \& Doloreux, D. (2009). Patterns of innovation in knowledge-intensive business services. Service Industries Journal, 29(4), 407-430. doi:10.1080/02642060802307847

Armbrust, M., Fox, A., Griffith, R., Joseph, A., Katz, R., Konwinski, A. e., Lee, G., Patterson, D., Rabkin, A., Stoica, I., \& Zaharia, M. (2010). A view of cloud computing. Communications of the ACM, 53(4), 50-58. doi:10.1145/1721654.1721672

Audretsch, D., \& Belitski, M. (2018). Mind the Gap: The Reverse Spillover of Knowledge and its Impact on Innovation Performance. Academy of Management Annual Meeting Proceedings, 2018(1).

Belal, H. M., Norani, N., Kosaka, M., Hasan, Q., \& Nordin, N. (2018). Knowledge Creating Service Company: A Case of Malaysian Logistics Company the Knowledge Creating Service Company: A Case Of Pkt Logistics View project Co-creation View project Knowledge Creating Service Company: A Case of Malaysian Logistics Company. ICSSI. Retrieved from https://www.researchgate.net/publication/332464574

Belk, R. W. (2017). Qualitative Research in Advertising. Journal of Advertising, 46(1), 36-47. doi:10.1080/0 0913367.2016.1201025

Boisot, M. (1999). Knowledge assets. Securing competitive advantage in the information economy. Oxford University Press. doi:10.1093/acprof:oso/9780198296072.001.0001

Borodako, K., Berbeka, J., \& Rudnicki, M. (2015). External and Internal Factors Motivating Outsourcing of Business Services by Meeting-Industry Companies: A Case Study in Krakow. Journal of Convention \& Event Tourism, 16(2), 93-115. doi:10.1080/15470148.2015.1013170

Borodako, K., Berbeka, J., \& Rudnicki, M. (2016). KIBS as a factor in meetings industry competitiveness creation in Krakow, Poland. In J. J. M. Ferreira, M. L. Raposo, C. I. Fernandes, \& M. Dejardin (Eds.), Knowledge Intensive Business Services and Regional Competitiveness (pp. 211-235). Routledge.

Borodako, K., Seweryn, R., Berbeka, J., Niemczyk, A., Davidson, R., \& Jakóbik, K. (2019). Assessment of the meetings industry's economic impact on the city of Krakow. Argumenta Oeconomica, 2(43). 191-211. doi:10.15611/aoe.2019.2.08

Borodako, K., Berbeka, J., \& Rudnicki, M. (2015). Innovation management in meetings industry. C.H. Beck.

Bouwman, H., den Hooff, V., van de Wijngaert, L., \& van Dijk, J. (2005). Information and communication technology in organizations: adoption, implementation, use and effects. Academic Press.

Bratinau, C., \& Orzea, I. (2010). Organizational knowledge creation. Marketing Challenges for Knowledge Society, 5(3), 41-62.

Brinberg, D. L., \& McGrath, J. (1985). Validity and the research process. Sage Publications.

Broersma, L., \& Van Ark, B. (2007). ICT, Business Services and Labour Productivity Growth. Economics of Innovation and New Technology, 16(6), 433-449. doi:10.1080/10438590600914429

Camacho, J. A., \& Rodriguez, M. (2005). How Innovative Are Services? An Empirical Analysis for Spain. Service Industries Journal, 25(2), 253-271. doi:10.1080/0264206042000305448

Castro Vergara, R. I., \& Marquina Feldman, P. S. (2018). Impact of broadband uses on labour demand derived from the innovative behaviour of firms in creative industries. Creative Industries Journal, 11(3), 278-305. do i: $10.1080 / 17510694.2018 .1523666$

Creswell, J. (2003). Research design: Qualitative, quantitative, and mixed method approaches (2nd ed.). Sage Publications.

Crouch, G. I., \& Ritchie, J. R. B. (1998). Convention site selection research: A review, conceptual model, and propositional framework. Journal of Convention \& Exhibition Management, 1(1), 49-69. doi:10.1300/ J143v01n01_05 
Davidson, R., \& Cope, B. (2003). Business Travel. Conferences, Incentive Travel, Exhibitions, Corporate Hospitality and Corporate Travel. Harlow: Pearson Education limited.

Dotson, P. C. (1995). Introduction to meeting management (2nd ed.). Professional Convention Management Association.

Flynn, M., \& Kowalkiewicz, M. (2016). Disruptive innovation typology: new technologies and business models in the professional services industry. Working Document: ISPIM Conference Paper Kuala Lumpur, 1-18.

Frank, A., Dalenogare, L., \& Ayala, N. (2019a). Industry 4.0 technologies: Implementation patterns in manufacturing companies. International Journal of Production Economics, 210(January), 15-26. doi:10.1016/j. ijpe.2019.01.004

Frank, A., Mendes, G., Ayala, N., \& Ghezzi, A. (2019b). Servitization and Industry 4.0 convergence in the digital transformation of product firms: A business model innovation perspective. Technological Forecasting and Social Change, 141(January), 341-351. doi:10.1016/j.techfore.2019.01.014

Friese, S. (2018). ATLAS.ti 8 Windows - User Manual. Berlin: ATLAS.ti 8 Windows - User Manual.

Gayá, R. E. (2018). Strengthening Knowledge Based Services in Argentina. RAM. Revista de Administração Mackenzie, 18(6), 96-123. doi:10.1590/1678-69712017/administracao.v18n6p96-123

Gerpott, T., Rams, W., \& Schindler, A. (2001). Customer retention, loyalty and satisfaction in the german mobile cellular telecommunications market. Telecommunications Policy, 25(4), 249-269. doi:10.1016/S03085961(00)00097-5

Goodpasture, J. C. (2015). Project Management the Agile Way: Making It Work In the Enterprise. Plantation: J. Ross.

Grado, S. C., Strauss, C. H., \& Lord, B. E. (1998). Economic impacts of conferences and conventions. Journal of Convention \& Exhibition Management, 1(1), 19-33. doi:10.1300/J143v01n01_03

Heinrichs, J. H., \& Lim, J. S. (2005). Model of organizational knowledge creation and strategic use of information. Journal of the American Society for Information Science and Technology, 56(6), 620-629. doi:10.1002/asi.20152

Hielscher, S., \& Will, M. G. (2014). Mental models of sustainability: Unearthing and analyzing the mental images of corporate sustainability with qualitative empirical research. Systems Research and Behavioral Science, 31(6), 708-719. doi:10.1002/sres.2305

Hoegl, M., \& Schulze, A. (2005). How to support knowledge creation in new product development: An investigation of knowledge management methods. European Management Journal, 23(3), 263-273. doi:10.1016/j. emj.2005.04.004

Hu, T.-S., Chang, S.-L., Lin, C.-Y., \& Chien, H.-T. (2006). Evolution of knowledge intensive services in a high-tech region - the case of Hsinchu, Taiwan. European Planning Studies, 14(10), 1363-1385. doi:10.1080/09654310600852530

Hübner, A., Holzapfel, A., \& Kuhn, H. (2015). Operations management in multi-channel retailing: An exploratory study. Operations Management Research, 8(3-4), 84-100. doi:10.1007/s12063-015-0101-9

ICCA. (2018a). International Congress and Convention Association 2017 ICCA Statistics Report. Retrieved from www.iccaworld.org

ICCA. (2018b). Meetings \& Events Industry Releases New Economic Impact Data. Retrieved from Meatings Mean Business website: https://www.iccaworld.org/knowledge/article.cfm?artid=548

ICCA. (2018c). Modern History of International Association Meetings 1963-2017. ICCA.

Janakiraman, S. (2012). Asia pacific business \& technology report: Growth and the importance of the MICE industry. Academic Press.

Jansen, R. J. G., Curşeu, P. L., Vermeulen, P. A. M., Geurts, J. L. A., \& Gibcus, P. (2011). Social capital as a decision aid in strategic decision-making in service organizations. Management Decision, 49(5), $734-747$. doi:10.1108/00251741111130823 
Kamp, B., \& Sisti, E. (2018). Assessing the relationship between ICT services and the manufacturing industry from a meso-economic perspective : Insights from the Basque Country. European Review of Service Economics \& Management, 2(6), 123-151.

Kite, G. (2018). A conduit for knowledge? demonstrating the strength of technology improvements in Indian firms that buy outsourced information technology. Journal of Evolutionary Economics, 28(2), 225-243. doi:10.1007/ s00191-018-0550-z

Kozinets, R. V. (2010). Netnography: Doing Ethnographic Research Online. Sage.

Landry, R., Amara, N., Lamari, M., \& Ouimet, M. (2007). How Innovative Are Services? An Empirical Analysis for Spain. International Journal of Entrepreneurship and Innovation Management, 7(2-5), 174-203.

Lee, E., \& Han, S. (2017). Mobile service consumption values: An exploratory mixed-method study. Information Technology Management, 18(4), 253-264. doi:10.1007/s10799-016-0263-7

Legg, D., \& Baker, J. (1987). Advertising Strategies for Services Firms. In C. Suprenant (Ed.), Add Value to Your Service (pp. 163-168). AMA.

Leszczynski, G., Zmyślony, P., \& Zieliński, M. (2014). Managing in Networks - From The Picture of Knowledge Network to Innovative Outcomes in Business Tourism Industry. In Formal and Informal Relationships in Networks. Industrial and Marketing Purchasing Group.

Lovelock, C. (1995). Competing On Service: Technology and teamwork in supplementary services. Planning Review, 23(4), 32-47. doi:10.1108/eb054517

Lowe, R., \& Ploetzner, R. (2017). Learning from Dynamic Visualization. Learning from Dynamic Visualization. doi:10.1007/978-3-319-56204-9

Lupo, T., \& Delbari, S. A. (2018). A knowledge-based exploratory framework to study quality of Italian mobile telecommunication services. Telecommunication Systems, 68(1), 129-144. doi:10.1007/s11235-017-0380-6

Madsen, P. M., \& Desai, V. (2010). Failing to learn? The effects of failure and success on organizational learning in the global orbital launch vehicle industry. Academy of Management Journal, 53(3), 451-476. doi:10.5465/ amj.2010.51467631

Magazzini, L., Pammolli, F., \& Riccaboni, M. (2012). Learning from failures or failing to learn? Lessons from pharmaceutical R\&D. European Management Review, 9(1), 45-58. doi:10.1111/j.1740-4762.2012.01027.x

Mair, J. (2015). Incentive travel: A theoretical perspective. Event Management, 19(4), 543-552. doi:10.3727/1 $52599515 X 14465748512803$

Martin de Castro, G., Lopez Saez, P., \& Novas Lopez, J. E. (2008). Processes of knowledge creation in knowledge-intensive firms: Empirical evidence from Boston's Route 128 and Spain. Technovation, 28(4), 222-230. doi:10.1016/j.technovation.2007.10.002

Martín, J. C., Román, C., \& Gonzaga, C. (2017). Quality of service and segmentation in the MICE industry: An approximation based on fuzzy logic. Journal of Convention \& Event Tourism, 18(1), 1-25. doi:10.1080/1 5470148.2016.1154808

Martinez, A., Vazquez, B., Estrada, H., Santillan, L., \& Zavala, C. (2017). Incorporating technology in serviceoriented i* business models: A case study. Information Systems and e-Business Management, 15(2), 461-487. doi:10.1007/s10257-016-0316-9

Mathieu, V. (2001). Service strategies within the manufacturing sector: Benefits, costs and partnership. International Journal of Service Industry Management, 12(5), 451-475. doi:10.1108/EUM0000000006093

Mell, P., \& Grance, T. (2009). The NIST definition of cloud computing. Academic Press.

Morse, J., \& Field, P.-A. (1995). Qualitative research methods (2nd ed.). Sage Publications.

Muller, E., \& Doloreux, D. (2009). What we should know about knowledge-intensive business services. Technology in Society, 31(1), 64-72. doi:10.1016/j.techsoc.2008.10.001

Nissen, M. E. (2006). Harnessing knowledge dynamics: principled organizational knowing, learning. IRM Press. doi:10.4018/978-1-59140-773-7 
Nissen, M. E. (2013). Harnessing dynamic knowledge principles in the technology-driven world. Harnessing Dynamic Knowledge Principles in the Technology-Driven World. doi:<ALIGNMENT.qj $><1$ ALIGNMENT $>10.4018 / 978-1-4666-4727-5$

Nonaka, I. (1994). A Dynamic Theory of Organizational Knowledge Creation. Organization Science, 5(1), 14-37. doi:10.1287/orsc.5.1.14

Nonaka, I., \& Toyama, R. (2007). Why Do Firms Differ? The Theory of the Knowledge- Creating Firm. In K. Ichijo \& I. Nonaka (Eds.), Knowledge creation and management. New challenges for managers. Oxford: Oxford University Press.

Nonaka, I., \& Takeuchi, H. (2006). Organizational knowledge creation. Creative Management and Development, 64-81. <ALIGNMENT.qj></ALIGNMENT>10.4135/9781446213704.n5

Pina, K., \& Tether, B. S. (2016). Towards understanding variety in knowledge intensive business services by distinguishing their knowledge bases. Research Policy, 45(2), 401-413. doi:10.1016/j.respol.2015.10.005

Preece, M. (2015). Managing Information and Knowledge in Service Industries. <ALIGNMENT.qj ></ ALIGNMENT > 10.1108/S1069-09642015000022B002

Ramadan, B. M., Dahiyat, S. E., Bontis, N., \& Al-dalahmeh, M. A. (2017). Intellectual capital, knowledge management and social capital within the ICT sector in Jordan. Journal of Intellectual Capital, 18(2), 437-462. doi:10.1108/JIC-06-2016-0067

Rogers, T. (2008). Conferences and Conventions. A Global Industry. Butterworth-Heinemann.

Segal-Horn, S. (2006). Strategy in service organizations. In D. Faulkner \& A. Campbell (Eds.), Oxford handbook of strategy (pp. 472-506). Oxford University Press.

Spender, J.-C. (1996). Making knowledge the basis of a dynamic theory of the firm. Strategic Management Journal, 17(S2), 45-62. doi:10.1002/smj.4250171106

Tether, B. S. (2005). Do services innovate (differently)? Insights from the European Innobarometer Survey. Industry and Innovation, 12(2), 153-184. doi:10.1080/13662710500087891

Thurston, T., \& Singh, V. (2010). Disrupting the consultants: Could the advisors use some advice? Thunderbird International Business Review, 52(1), 61-65. doi:10.1002/tie.20311

Torre, A., \& Rallet, A. (2005). Proximity and localisation. Regional Studies, 39(1), 47-59. doi:10.1080/0034340052000320842

Ulaga, W., \& Eggert, A. (2006). Value-Based Differentiation in Business Relationships: Gaining and Sustaining Key Supplier Status. Journal of Marketing, 70(1), 119-136. doi:10.1509/jmkg.2006.70.1.119

UNWTO. (2006). Measuring the Economic Importance of the Meetings Industry - Developing a Tourism Satellite Account Extension. Madrid: UNWTO.

Urbinati, A., Bogers, M., Chiesa, V., \& Frattini, F. (2019). Creating and capturing value from Big Data: A multiple-case study analysis of provider companies. Technovation, 84-85(January), 21-36. <ALIGNMENT. qj $></$ ALIGNMENT $>10.1016 /$ j.technovation.2018.07.004

Wang, W. T., Ou, W. M., \& Chen, W. Y. (2019). The impact of inertia and user satisfaction on the continuance intentions to use mobile communication applications: A mobile servicpe quality erspective. International Journal of Information Management, 44, 178-193. doi:10.1016/j.ijinfomgt.2018.10.011

Whitfield, J., Dioko, L. D. A., Webber, D., \& Zhang, L. (2014). Attracting convention and exhibition attendance to complex MICE venues: Emerging data from Macao. International Journal of Tourism Research, 16(2), 169-179. doi:10.1002/jtr.1911

Windrum, P., \& Tomlinson, M. (1999). Knowledge-intensive services and international competitiveness: A four country comparison. Technology Analysis and Strategic Management, 11(3), 391-408. doi:10.1080/095373299107429

Wollersheim, J., Pfaff, M., \& Krcmar, H. (2014). Information Need in Cloud Service Procurement - An Exploratory Case Study. 10.1007/978-3-319-10491-1_3 
Yan, Z., Wen, Z., \& Huesig, S. (2010). Innovation as Clusters in Knowledge Intensive Business Services: Taking ICT Services in Shanghai and Bavaria as an Example. International Journal of Innovation Management, 14(1), 1-18. doi:10.1142/S1363919610002520

Zelger, J. (2004). WinRelan; Windows Relation Analysis. University of Innsbruck - Department of Philosophy.

Zelger, J. (2008). The representation of verbal data by GABEK-nets (J. Zelger, M. Raich, \& P. Schober, Eds.). Studienverlag.

Zollo, M., \& Winter, S. G. (2003). Deliberate Learning and the Evolution of Dynamic Capabilities. Organization Science, 13(3), 339-351. doi:10.1287/orsc.13.3.339.2780

Krzysztof Borodako (Ph.D.) is a Professor in the Tourism Department at Cracow University of Economics (Kraków, Poland). Prof. Borodako is an author or co-author of over 100 publications concerning innovation, business services, tourism, new technologies, event management, foresight (strategic planning). He has been the principal investigator in many research projects. He reviews manuscripts for journals on the JCR list. His main areas of research interest are the meetings industry (including congresses and trade fairs), knowledge intensive business services, and foresight.

Jadwiga Berbeka (Ph.D.) is a Professor in the Tourism Department at Cracow University of Economics (Kraków, Poland). Prof. Berbeka is an author or co-author of over 140 publications concerning innovation, business services, consumer behavior, knowledge transfer, new technologies and tourism. She has been the principal investigator in many research projects. She reviews manuscripts for journals on the JCR list. Her main areas of research interest are knowledge intensive business services, consumer behavior, tourism.

Michat Rudnicki (Ph.D.) is an Assistant Professor in the Tourism Department at Cracow University of Economics (Kraków, Poland). Ph.D. Rudnicki is an author or co-author of over 50 publications concerning innovation, business services, knowledge transfer, tourism, new technologies and transport. He has been the principal investigator in a few research projects. His main areas of research interest are the new technologies in tourism and knowledge intensive business services. 